\title{
The Efficacy of Potential Probiont Bacillus amylolique- faciens Strain L11 in Protecting Artemia Nauplii and Blue Crab Juveniles against Vibrio harveyi Infection
}

\author{
Azrin N.A.R. ${ }^{1}$, Yuzine E. ${ }^{1}$, Ina-Salwany M.Y. ${ }^{1,2}$ and Murni Karim ${ }^{1,2 *}$ \\ ${ }^{1}$ Department of Aquaculture, Faculty of Agriculture, Universiti Putra Malaysia, 43400, Serdang, Selangor, Malaysia. \\ ${ }^{2}$ Laboratory of Marine Biotechnology, Institute of Bioscience, Universiti Putra Malaysia, 43400, Serdang, Selangor, \\ Malaysia.
}

\begin{abstract}
In this study, Bacillus amyloliquefaciens strain L11 was used as potential probiont in preliminary in vivo assay using Artemia and blue crab juveniles as final host. Strain L11 at $10^{8} \mathrm{CFU} \mathrm{mL}^{-1}$ was found able to penetrate into gnotobiotic Artemia as early as $6 \mathrm{~h}$ exposure. The survival rate of Artemia incubated with strain L11 at concentration of $10^{6} \mathrm{CFU} \mathrm{ml}^{-1}$ and challenged with $V$. harveyi was $62 \pm 1 \%$. The numbers of Vibrios in Artemia were reduced at the end of the challenge assay. The in vivo assay using blue crab juveniles, demonstrated that strain $\mathrm{L} 11$ at $10^{6} \mathrm{CFU} \mathrm{mL}^{-1}$ showed significant survival (42 $\pm 1 \%$ ) compared with group challenged with $V$. harveyi with no probiont added (12 $\pm 1 \%)$ after five days of exposure. Strain L11 also able to reduce the number of Vibrios and increased the weight of the juveniles.

Keywords: Bacillus amyloliquefaciens, Artemia nauplii, blue crab juveniles, Vibrio harveyi.
\end{abstract}

\footnotetext{
*Correspondence: murnimarlina@upm.edu.my; +60389474996
}

(Received: 09 April 2019; accepted: 24 May 2019)

Citation: Azrin N.A.R., Yuzine E., Ina-Salwany M.Y. and Murni Karim, The Efficacy of Potential Probiont Bacillus amyloliquefaciens Strain L11 in Protecting Artemia Nauplii and Blue Crab Juveniles against Vibrio harveyi Infection, J Pure Appl Microbiol., 2019; 13(2): 923-931. doi: 10.22207/JPAM.13.2.29

(C) The Author(s) 2019. Open Access. This article is distributed under the terms of the Creative Commons Attribution 4.0 International License which permits unrestricted use, sharing, distribution, and reproduction in any medium, provided you give appropriate credit to the original author(s) and the source, provide a link to the Creative Commons license, and indicate if changes were made. 


\section{INTRODUCTION}

Aquaculture is known as one of the fastest food-production industries in the world. However, it suffers from economic loss due to diseases causes by bacteria infection (Frans et al., 2011). In crab cultures, especially, during Portunus pelagicus larvae culture production, low or zero survival and high mortality rate occur due to bacterial infections particularly cause by Vibrio harveyi (Talpur et al., 2011). The most common symptoms of the disease are the larvae and juveniles will be fluorescent in dark light, loss of appetite leading to reduce growth rate and dark in hepatopancreas (Jithendran et al., 2010).

To overcome the problem, probiotic is an alternative way to control Vibrio sp. in crustacean cultures. Verschuere et al. (2000) stated that probiotics have beneficial effect to modify the microbial community which can enhanced its nutritional value and improve the environmental condition from the bacterial infections. There are several ways that the probiotic can be delivered to the culture system such as via food sources and formulation in the water. Artemia is essential in marine finfish and shellfish hatchery operations as a simple food during the earliest life stages and have been proven as a probiotic carrier (Hai et al., 2010). Even though there has been an improvement in fish nutrition industry there is still no artificial feed formulation available to completely substitute for Artemia.

In this study, Bacillus amyloliquefaciens strain L11 was chosen for in vivo tests since it had a good potential as probiont in antagonistic activity of co-culture assay towards $V$. harveyi and biofilm formation assay (Azrin et al., 2017). Blue crab juveniles were used in this study since it is known as crucial stage before they enter adult's stage which tend to get expose to the disease. The aim of this study was to evaluate the potential of $B$. amyloliquefaciens strain L11 as probiont in protecting Artemia and blue crab juveniles against $V$. harveyi infection. This study is important to be carried out in order to provide alternative ways for future farming of healthy blue crabs.

\section{MATERIALS AND METHODS Bacterial isolates}

B. amyloliquefaciens strain L11 isolated from adults of $P$. pelagicus (Azrin et al., 2017) was cultured in Tryptic Soy Agar (TSA) supplemented with $1.5 \%$ of $\mathrm{NaCl}$ while $V$. harveyi was grown on Thiosulphate Bile Salt (TCBS) and incubated at $30^{\circ} \mathrm{C}$ for $24 \mathrm{~h}$. Then, strain L11 and pathogenic $V$. harveyi were inoculated individually in $10 \mathrm{~mL}$ of Tryptic Soy Broth (TSB) supplemented with 1.5\% $\mathrm{NaCl}$ for overnight at $30^{\circ} \mathrm{C}$ in the incubator shakers (Innova \& 42R) at $120 \mathrm{rpm}$. Next, the isolate was washed, centrifuged (Eppendorf, 5804R) at 5000 rpm for 10 minutes and suspended using sterilized saline for three times. The required concentration was adjusted prior to use.

\section{Colonization of probiont in gnotobiotic Artemia nauplii}

A 200 mg Artemia cyst (Bio-Marine brand) was put into a falcon tube containing $18 \mathrm{~mL}$ of tap water. Next, the cyst suspension was aerated for one hour at room temperature. After incubation, $660 \mu \mathrm{L} \mathrm{NaOH}+10 \mathrm{~mL} \mathrm{NaOCl}$ was added to the cyst suspension. Then, the cyst suspensions were mixed regularly by using $1000 \mu \mathrm{L}$ micro-pipette. Next, $\mathrm{Na}_{2} \mathrm{~S}_{2} \mathrm{O}_{3}$ was added to stop the reaction. The cyst suspension was passed over a $100 \mu \mathrm{m}$ sieve and rinsed with seawater. The cysts were transferred to a new sterile falcon tube containing $30 \mathrm{~mL}$ of FSSW and put on rotator and left for $24 \mathrm{~h}$ to hatch. All the steps were done under laminar flow to prevent contamination.

Twenty Artemia nauplii were divided into new sterile falcon tubes with $30 \mathrm{~mL}$ of sterile seawater each. Strain L11 was added into the falcon tubes separately with different concentrations $\left(10^{6} \mathrm{CFU} \mathrm{mL} L^{-1}\right.$ and $10^{8} \mathrm{CFU} \mathrm{mL}^{-1}$ ) and no probiont was added into control tubes. The falcon tubes were then placed onto a rotator which was set to medium speed. Each treatment was observed at $0,6,12,24$ and $48 \mathrm{~h}$ and all the treatments were run in triplicate.

After that, the Artemia nauplii were separated from culture water of each treatment by passed over the Artemia in a sterile $100 \mu \mathrm{m}$ mesh siever. The Artemia were rinsed with filtered sterile seawater (FSSW) for three times and suspended in $1 \mathrm{~mL}$ of saline before homogenized. Next, the suspension underwent a serial dilution before being plated on TSA plates to quantify the numbers of strain L11 that able to penetrate the Artemia. After $24 \mathrm{~h}$ of incubation at $30^{\circ} \mathrm{C}$, the bacterial counts was done using ROCKER galaxy 230 colony counters and recorded. 
Lethal concentration at $\mathbf{5 0 \%}$ endpoint $\left(\mathrm{LC}_{50}\right)$ test against Vibrio harveyi

Twenty blue crab juveniles with average weight of $50 \mathrm{mg}$ and $5 \mathrm{~mm}$ in length were added to each aquarium contained $5 \mathrm{~L}$ of disinfected seawater. Each treatment was conducted in triplicate. A pathogenic $V$. harveyi was added to final concentrations of $10^{2} \mathrm{CFU} \mathrm{mL}^{-1}(\mathrm{~T} 1), 10^{4} \mathrm{CFU}$ $\mathrm{mL}^{-1}$ (T2), $10^{6} \mathrm{CFU} \mathrm{mL}{ }^{-1}$ (T3) and $10^{8} \mathrm{CFU} \mathrm{mL}^{-1}$ (T4) in respective aquarium. Aquaria containing blue crab juveniles only (without $V$. harveyi) was served as survival control (TO). The mortality percentage of the larvae reached 50\% was recorded and graph was plotted to determine the $\mathrm{LC}_{50}$ of pathogen which then be used in challenge assay.

Preliminary in vivo assay using Artemia fransiscana nauplii

In vivo Artemia nauplii challenge

The Artemia cysts were hatched in 35 ppt FSSW with continued aeration and high light intensity at $30^{\circ} \mathrm{C}$ for $24 \mathrm{~h}$. After $24 \mathrm{~h}$ of hatching, 20 Artemia nauplii were divided into falcon tubes containing $30 \mathrm{ml}$ of FSSW. Artemia were fed with yeast. Then, Artemia nauplii were preincubated with probiont strain L11 at two different concentrations $\left(10^{6}\right.$ and $10^{8} \mathrm{CFU} \mathrm{\textrm {mL } ^ { - 1 } )}$ on the first day respectively. The concentrations were chosen based on $\mathrm{LC}_{50}$ results. On the next day, the Artemia nauplii were challenged with $V$. harveyi at concentration of $10^{5} \mathrm{CFU} \mathrm{mL}^{-1}$. Artemia nauplii without any probiont and pathogen added was act as control. Treatments with probiont and $V$. harveyi only were served as survival and mortality control respectively. The treatment and control groups were conducted in triplicate. The falcon tubes containing Artemia were put on rotator with medium speed and Artemia were fed with yeast once daily. Observation was made until $50 \%$ mortality was reached in group with $V$. harveyi only and marked as the end of the experiment. The mortality was recorded every day during the experiment.

\section{Vibrios count}

Vibrios counts were done by separating the Artemia from culture water by filtering through $100 \mu \mathrm{m}$ mesh. Then, Artemia trapped in the sieve were washed three times using FSSW before homogenized using sterilized homogenizer. Serial dilutions were performed to quantify the numbers of vibrios in the Artemia. A $100 \mu \mathrm{L}$ of each sample was plated out on TCBS and incubated for overnight at $30^{\circ} \mathrm{C}$. The colonies of Vibrios harveyi were counted and recorded.

Safety test of potential probionts on blue crab juveniles

Seawater for juvenile culture

UV treated seawater was filtered through a $10 \mu \mathrm{m}$ net and then sterilized with sodium hypochlorite $(\mathrm{NaOCl})(50 \mathrm{mg} / \mathrm{L})$ for $24 \mathrm{~h}$. This procedure eliminated almost all naturally occurring bacteria in water, followed by neutralization with sodium thiosulphate $\left(\mathrm{Na}_{2} \mathrm{~S}_{2} \mathrm{O}_{3}\right)$.

\section{Water Parameters}

Temperature ranged from $27^{\circ} \mathrm{C}$ to $29^{\circ} \mathrm{C}$ in treatment tanks and controls. Salinity remained at $30 \mathrm{ppt}$ in treated groups and controls. Dissolved oxygen ranged from $6.01-6.05 \mathrm{mg} / \mathrm{L}$ in treated groups and controls. While $\mathrm{pH}$ ranged from 8.00 8.31 in treated and controls.

\section{Experimental design}

A number of blue crab juveniles (20) with average weight $50 \mathrm{mg}$ and $5 \mathrm{~mm}$ in length were divided into aquarium containing $5 \mathrm{~L}$ of disinfected seawater. Aeration was provided continuously. On the next day, strain L11 was added to the treatments groups according to final concentrations of $10^{6} \mathrm{CFU} \mathrm{mL}^{-1}$ and $10^{8} \mathrm{CFU} \mathrm{mL}^{-1}$ through immersion technique. The experiment was run in triplicates. Observation was made for seven days and mortality was recorded.

In vivo bacterial challenge assay using blue crab juveniles

\section{Experimental design}

This method is based on Talpur et al. (2012) with minor modifications on the numbers of crabs used. A number of crab juveniles (20) with average weight $50 \mathrm{mg}$ and $5 \mathrm{~mm}$ in length were added to each $10 \mathrm{~L}$ aquaria contained 5 $L$ of disinfected seawater. Each treatment was conducted in triplicates. Strain L11 was added to the final concentrations of $10^{6} \mathrm{CFU} \mathrm{mL} \mathrm{m}^{-1}$ and $10^{8}$ CFU mL ${ }^{-1}$ on day one in respective treatments.

After $24 \mathrm{~h}$ incubation, $V$. harveyi with concentrations of $10^{5} \mathrm{CFU} \mathrm{mL}{ }^{-1}$ was added for challenge. Aquaria containing non-inoculated juveniles was served as survival control, while those inoculated with the pathogen only was served as mortality control. Aquaria treated with probiont strain L11 was served as probiotic control and aquaria with the mixture of probiotic 
and pathogen as treatments. Juveniles were maintained at $28^{\circ} \mathrm{C}$ and $31 \mathrm{ppt}$ throughout the experiment. All aquaria were provided with continuously aeration. All juveniles were fed with commercial diet that contained no probiotic. Then, the survival of the juveniles were observed and recorded.

\section{Vibrios count}

A total plate count of Vibrio spp. was done in order to determine the effect of potential probiont on presumptive Vibrios count (yellow colony-forming, green colony-forming and luminous Vibrio count) in cultured water and crab juveniles. The samples were collected at the end of the experiment after living and dead juveniles were counted. The juvenile were filtered using nylon mesh $(75 \mu \mathrm{m})$ and washed three times with FSSW. The juveniles were then collected and placed into a sterile eppendorf tube and homogenized using sterile homogenizer. A serial dilution of the homogenized juveniles were made and $100 \mu \mathrm{L}$ of each dilution was pipetted and spread evenly onto TCBS agar medium. Each sample was run in triplicates. The plates were incubated for $24 \mathrm{~h}$ at $30^{\circ} \mathrm{C}$ and colony forming unit were counted on the next day. Water samples from each treatment were also collected, diluted and plated using the same method as juveniles.

\section{Growth rate}

The growth rate of the blue crab was measured based on weight and mean length over culture period. The initial length and weight were measured at the beginning of the experiment and the final length and weight were measured at the end of the experiment.

\section{RESULTS}

Probiont colonization in gnotobiotic Artemia nauplii

In axenic Artemia, results demonstrated that strain $\mathrm{L} 11$ at $10^{8} \mathrm{CFU} \mathrm{mL^{-1 }}$ able to colonize as early as $6 \mathrm{~h}$ to the Artemia. However, strain L11 at $10^{6} \mathrm{CFU} \mathrm{mL} \mathrm{m}^{-1}$ colonized in Artemia after $12 \mathrm{~h}$ of exposure (Fig. 1 \& 2).

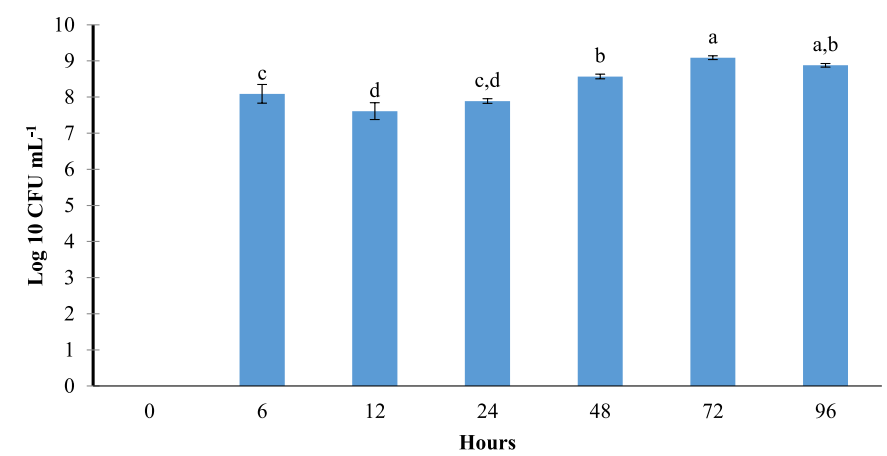

Fig. 1. The concentrations of probiont Bacillus amyloliquefaciens L11 in Artemia at different time point. The Artemia

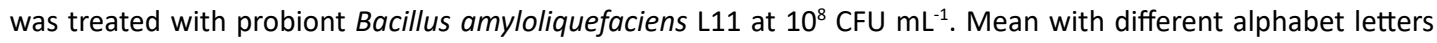
indicates significant difference

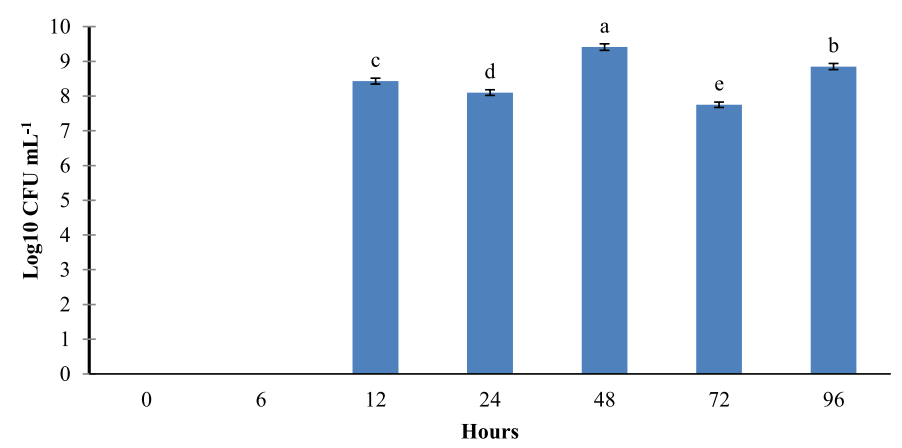

Fig. 2. The concentrations of probiont Bacillus amyloliquefaciens L11 in Artemia at different time point. The Artemia was treated with probiont Bacillus amyloliquefaciens $\mathrm{L} 11$ at $10^{6} \mathrm{CFU} \mathrm{mL}{ }^{-1}$. Mean with different alphabet letters indicates significant difference 
Lethal concentration at $\mathbf{5 0 \%}$ endpoint $\left(\mathrm{LC}_{50}\right)$ test

Fifty percent mortality of the crab

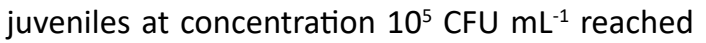
after four days pre incubated with $V$. harveyi (Fig. $3)$. High mortalities $(70 \pm 1)$ were occurred in higher concentration $\left(10^{8} \mathrm{CFU} \mathrm{mL} \mathrm{mL}^{-1}\right)$ of $V$. harveyi.

Preliminary in vivo assay on Artemia nauplii Survival and vibrios count

After five days of observation, results showed strain L11 was not harmful to the Artemia and able to confer protection towards Artemia against $V$. harveyi (Fig. 4). Artemia treated with strain L11 at concentration $10^{6} \mathrm{CFU} \mathrm{mL} \mathrm{mL}^{-1}$ (T5) had higher survival (62 $\pm 1 \%$ ) after challenged with $V$. harveyi and significantly different with $V$. harveyi only (T4, $3 \pm 0.3 \pm 0)$. In addition, all treatments showed significant different in survival as compared to group with $V$. harveyi only. Artemia

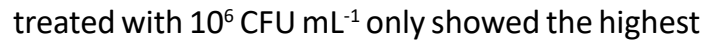
survival $(67 \pm 2 \%$ ) after pre-incubated with strain L11.

The Vibrios count in Artemia showed that strain L11 was able to reduce the numbers of Vibrio at the end of the challenged assay (Table 1). Group

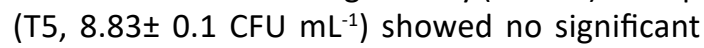
different in the number of Vibrio compared to

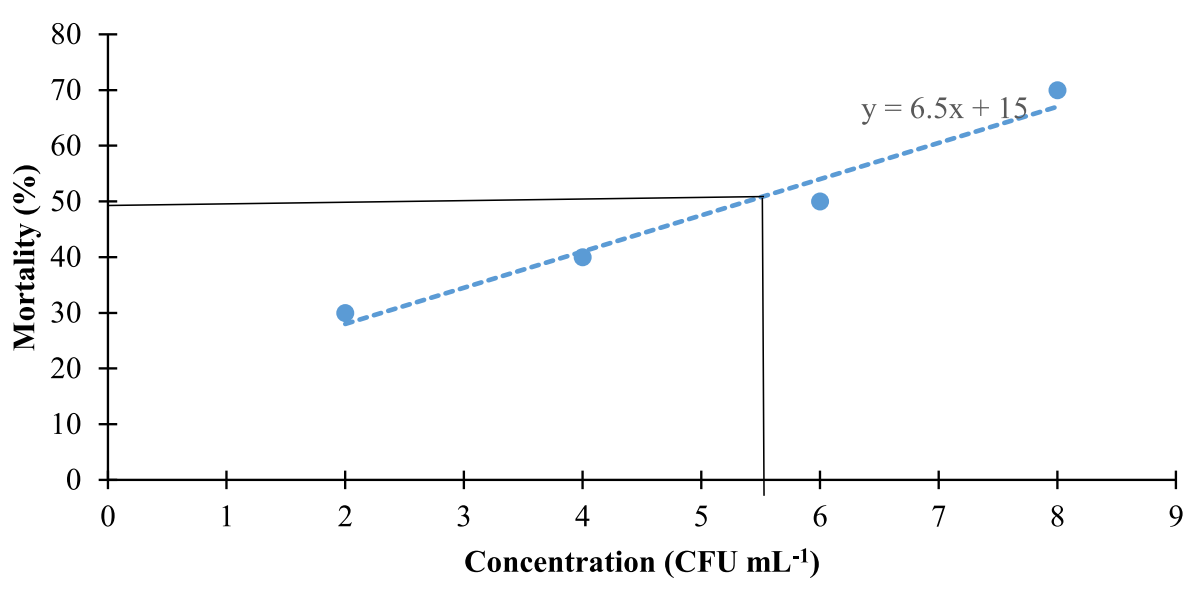

Fig. 3. The $\mathrm{LC}_{50}$ of the different Vibrio harveyi concentrations were determined by incubated crab juvenile with Vibrio harveyi as preparation for challenged test. Vibrio harveyi at different concentration $\left(10^{2}, 10^{4}, 10^{6}\right.$ and $10^{8}$ $\mathrm{CFU} \mathrm{mL}{ }^{-1}$ ) was used for the test.

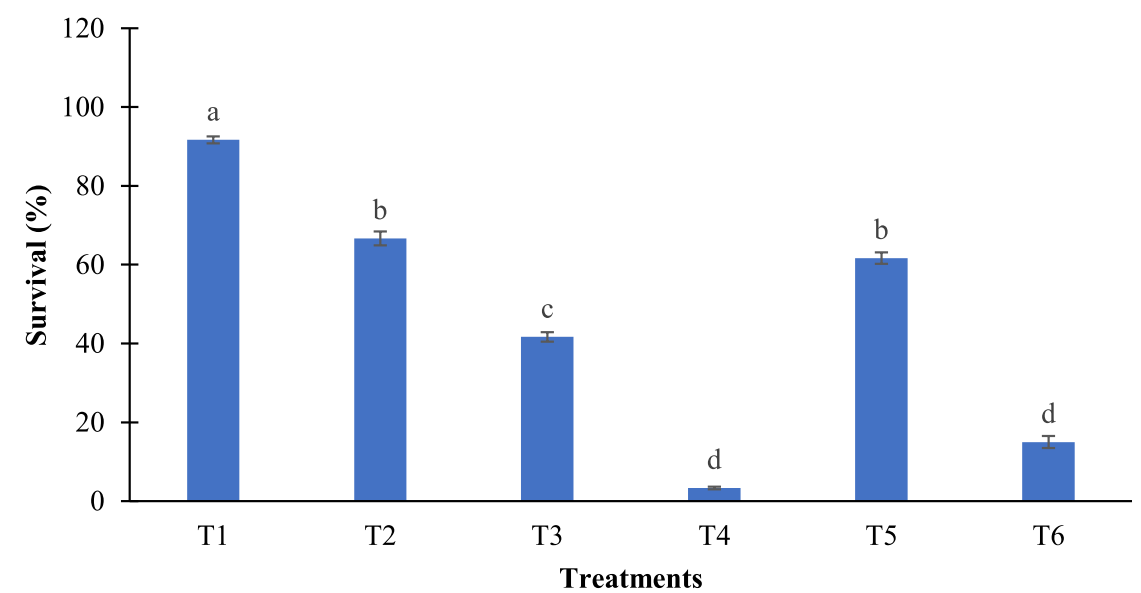

Fig. 4. Survival of Artemia after pre incubated with different concentrations of probiont Bacillus amyloliquefaciens

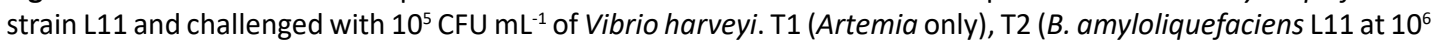
$\mathrm{CFU} \mathrm{mL} \mathrm{m}^{-1}$ ), T3 (B. amyloliquefaciens $\mathrm{L} 11$ at $10^{8} \mathrm{CFU} \mathrm{mL}^{-1}$ ), T4 (V. harveyi at $10^{5} \mathrm{CFU} \mathrm{mL}^{-1}$ only), T5 (B. amyloliquefaciens $\mathrm{L} 11$ at $10^{6} \mathrm{CFU} \mathrm{mL} \mathrm{m}^{-1}+V$. harveyi at $\left.10^{5} \mathrm{CFU} \mathrm{mL}{ }^{-1}\right), \mathrm{T} 6$ (B. amyloliquefaciens $\mathrm{L} 11$ at $10^{8} \mathrm{CFU} \mathrm{mL}^{-1}+\mathrm{V}$. harveyi at $10^{5} \mathrm{CFU}$ $\left.\mathrm{mL}^{-1}\right)$. Error bars indicates standard error (S.E). Mean with different alphabet letters indicates significant difference 
Table 1. Vibrio count in Artemia after pre-incubated at different concentration of Bacillus amyloliquefaciens

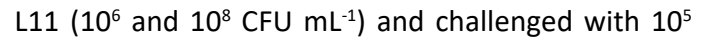
$\mathrm{CFU} \mathrm{mL} \mathrm{m}^{-1}$ of Vibrio harveyi. Different alphabet indicated significant different among treatments $(p<0.05)$

\begin{tabular}{|c|c|c|}
\hline $\begin{array}{l}\text { Treat- } \\
\text { ments }\end{array}$ & Descriptions & $\begin{array}{l}\text { Log10 } \\
\text { CFU mL } \mathrm{mL}^{-1}\end{array}$ \\
\hline $\mathrm{T} 4$ & V. harveyi at $10^{5} \mathrm{CFU} \mathrm{mL}^{-1}$ & $9.14 \pm 0.1^{\mathrm{a}}$ \\
\hline T5 & $\begin{array}{l}\text { B. amyloliquefaciens } \mathrm{L} 11 \\
10^{6} \mathrm{CFU} \mathrm{\textrm {mL } ^ { - 1 }},+\mathrm{V} \text {. harveyi } \\
\text { at } 10^{5} \mathrm{CFU} \mathrm{\textrm {mL } ^ { - 1 }}\end{array}$ & $8.83 \pm 0.1^{\mathrm{a}, \mathrm{b}}$ \\
\hline T6 & $\begin{array}{l}\text { B. amyloliquefaciens } \mathrm{L} 11 \\
10^{8} \mathrm{CFU} \mathrm{\textrm {mL } ^ { - 1 }},+\mathrm{V} \text {. harveyi } \\
\text { at } 10^{5} \mathrm{CFU} \mathrm{\textrm {mL } ^ { - 1 }}\end{array}$ & $8.65 \pm 0.09^{b}$ \\
\hline
\end{tabular}

group with $V$. harveyi only $\left(\mathrm{T} 4,9.14 \pm 0.1 \mathrm{CFU} \mathrm{mL} \mathrm{m}^{-1}\right)$. However, probiont strain L11 at concentration of $10^{8} \mathrm{CFU} \mathrm{mL} \mathrm{mL}^{-1}$ (T6), showed significant different in number of Vibrio loads with $8.65 \pm 0.09 \mathrm{CFU} \mathrm{mL} \mathrm{m}^{-1}$ compared to group of $V$. harveyi only.

\section{Blue crab juveniles challenge test Survival}

After five days, group of strain L11 at concentration of $10^{6} \mathrm{CFU} \mathrm{\textrm {mL } ^ { - 1 }}$ and challenged with $V$. harveyi had significant survival (42 \pm $1 \%)$ compared to the challenged group with no probiont added $(12 \pm 1 \%)$ indicated protection effect conferred by the probiont. Non-challenged group with probiont showed no significant survival $(60 \pm 1 \%)$ compared to the control group (58 $\pm 1 \%)$
(Fig. 5). This demonstrated that the probiont was not harmful to the juveniles.

\section{Vibrios count}

Strain L11 was able to reduce number of Vibrios in crab juvenile and as well as in water culture compared with crab juveniles with $V$. harveyi only (Table 2). Vibrios count in crab juveniles with no probiont added was higher (7.05 $\pm 1 \mathrm{CFU} \mathrm{mL}^{-1}$ ) compared with group with the addition of strain L11 (4.87 $\left.\pm 1 \mathrm{CFU} \mathrm{mL}^{-1}\right)$. However, there was no significant different between those two groups.

There was a significant different in reduction of Vibrios in culture water added with probiont compared with treatment without probiont added. Vibrios count in group of $V$. harveyi was $6.56 \pm 1.2 \mathrm{CFU} \mathrm{mL}^{-1}$ while with addition of probiont was $7.27 \pm 1.5 \mathrm{CFU} \mathrm{mL}^{-1}$ (Table 3).

Table 2. Vibrios count in crab juvenile after preincubated with probiont $B$. amyloliquefaciens L11

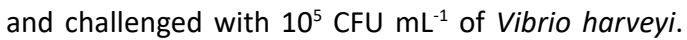
Different alphabet indicated significant different among treatments $(p<0.05)$

\begin{tabular}{|c|c|c|}
\hline $\begin{array}{l}\text { Treat- } \\
\text { ments }\end{array}$ & Descriptions & $\begin{array}{l}\text { Log10 } \\
\text { CFU } \mathrm{mL}^{-1}\end{array}$ \\
\hline T3 & $\begin{array}{l}\text { B. amyloliquefaciens } \mathrm{L} 11 \\
10^{6} \mathrm{CFU} \mathrm{\textrm {mL } ^ { - 1 }}+\mathrm{V} \text {. harveyi } \\
\text { at } 10^{5} \mathrm{CFU} \mathrm{\textrm {mL } ^ { - 1 }}\end{array}$ & $7.05 \pm 1^{\mathrm{a}}$ \\
\hline T4 & V. harveyi at $10^{5} \mathrm{CFU} \mathrm{\textrm {mL } ^ { - 1 }}$ & $4.87 \pm 1^{\mathrm{a}}$ \\
\hline
\end{tabular}

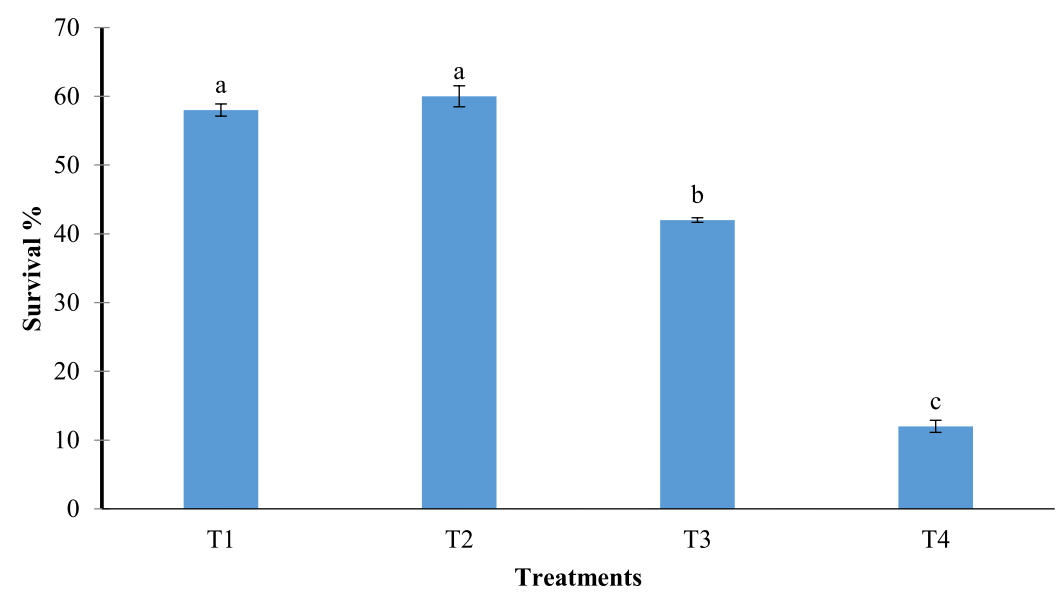

Fig. 5. Survival of crab juveniles treated with probiont Bacillus amyloliquefaciens strain L11 at concentration of $10^{6}$ CFU mL $\mathrm{mL}^{-1}$ and challenged with Vibrio harveyi at $10^{5} \mathrm{CFU} \mathrm{mL}^{-1}$. T1 (control, crab only), T2 (B. amyloliquefaciens L11 at $\left.10^{6} \mathrm{CFU} \mathrm{mL}{ }^{-1}\right), \mathrm{T} 3\left(\right.$ B. amyloliquefaciens $\mathrm{L} 11$ at $10^{6} \mathrm{CFU} \mathrm{mL}^{-1}+V$. harveyi at $\left.10^{5} \mathrm{CFU} \mathrm{\textrm {mL } ^ { - 1 }}\right)$, T4 (V. harveyi at $10^{5}$ $\mathrm{CFU} \mathrm{mL}^{-1}$ only). Mean with different alphabet letters indicates significant difference 
Table 3. Vibrios count in water samples after preincubated with probiont $B$. amyloliquefaciens L11

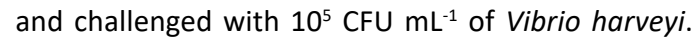
Different alphabet indicated significant different among treatments $(p<0.05)$

\begin{tabular}{lll}
\hline $\begin{array}{l}\text { Treat- } \\
\text { ments }\end{array}$ & Descriptions & $\begin{array}{l}\text { Log10 } \\
\text { CFU } \mathrm{mL}^{-1}\end{array}$ \\
\hline T3 & $\begin{array}{l}\text { B. amyloliquefaciens L11 } \\
10^{6} \mathrm{CFU} \mathrm{mL}^{-1},+ \text { V. harveyi } \\
\end{array}$ & $7.27 \pm 1.5^{\mathrm{a}}$ \\
at $10^{5} \mathrm{CFU} \mathrm{mL}^{-1}$ & \\
T4 & V. harveyi at $10^{5} \mathrm{CFU} \mathrm{mL}^{-1}$ & $6.56 \pm 1.2^{\mathrm{b}}$ \\
\hline
\end{tabular}

\section{Specific Growth rate (SGR)}

The weight of blue crab juveniles treated with strain $\mathrm{L} 11$ at concentration $10^{6} \mathrm{CFU} \mathrm{mL}{ }^{-1}$ was increased slightly compared to control (Fig. 6). The increased was significant if compared between treatments without probiont. In addition, the growth rate of the crab treated with probiont and challenged with $V$. harveyi also showed an increased in growth rate but it was not significant compared with $V$. harveyi only. Other than that, the juveniles with $V$. harveyi only was slower in growth as compared with other treatment. The

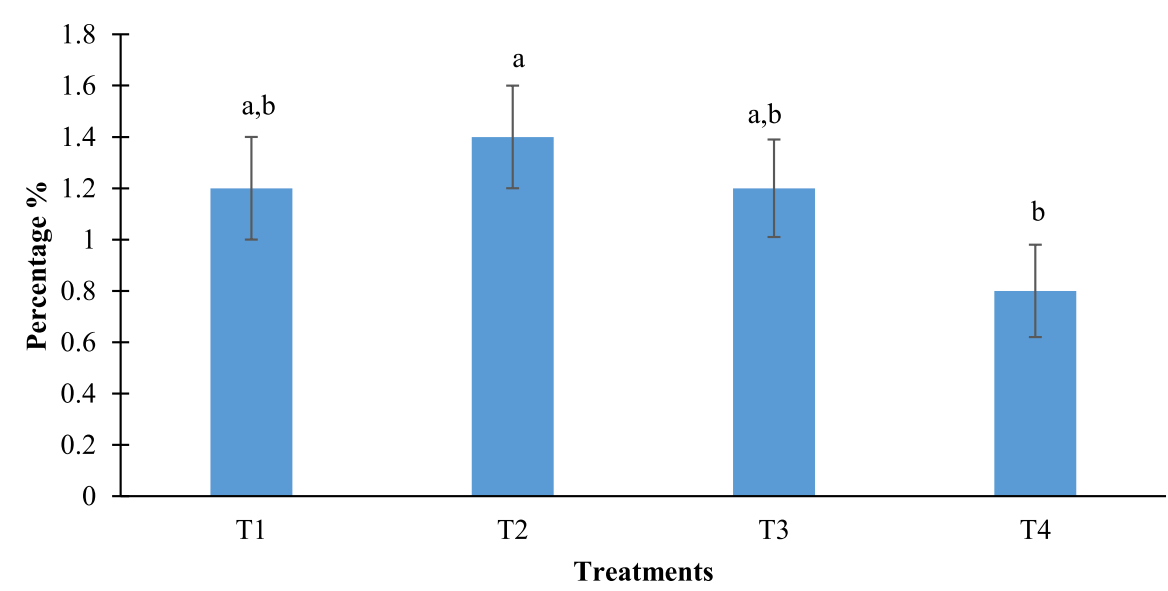

Fig. 6. Specific growth rate of the of the blue crab juvenile treated with probiont Bacillus amyloliquefaciens strain L11 at $10^{6} \mathrm{CFU} \mathrm{mL}{ }^{-1}$ against Vibrio harveyi after 5 days of challenged test. T1 (control, crab only), T2 (strain L11 at $10^{6} \mathrm{CFU} \mathrm{mL}{ }^{-1}$ ), T3 (strain L11 at $10^{6} \mathrm{CFU} \mathrm{\textrm {mL } ^ { - 1 }}+\mathrm{V}$. harveyi at $10^{5} \mathrm{CFU} \mathrm{\textrm {mL } ^ { - 1 }}$ ), T4 (V. harveyi at $10^{5} \mathrm{CFU} \mathrm{mL}^{-1}$ only). Mean with different alphabet letters indicates significant difference

growth rate was ranging between $0.8 \%$ to $1.4 \%$ in treatments after five days of challenged.

\section{Mean length increment}

No significant difference in length was observed in all groups. The length of the juveniles increased $2 \%$ in all treatments.

\section{DISCUSSION}

According to Tan et al. (2016) probiotics are being used instead of antibiotic since it is shown to improve survival rate, growth and provide better health status of the host. Other than that, it also stimulates the immune response of the organism against disease and infection (Neway-Fyzul et al., 2014). In aquaculture system, probiotic can be delivered to the culture organism through formulated feed or directly dispersed into the water. In hatchery, life feed such Artemia fransiscana was used as carrier of probiotics to fish and crustaceans (Hai et al., 2010). In this study, Artemia was used as a host in preliminary in vivo challenged test and for probiotic colonization test. Results demonstrated that probiont strain L11 was able to colonize in Artemia body as early as $6 \mathrm{~h}$ after pre incubated at two different concentrations which were $10^{6}$ and $10^{8} \mathrm{CFU} \mathrm{mL} \mathrm{mL}^{-1}$ respectively. According to Korkea-Aho et al. (2012) and Lazado et al. (2011), probiotic bacteria that enter the host body will be colonized and occupied the digestive tract site and growth in intestinal mucus site in order to compete with the pathogen (Sorroza et al., 2012).

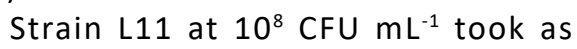
early as six hours to penetrate into the Artemia body. The results was in line with Campbell et al. (1993) which demonstrated that formalinkilled bacteria showed maximum uptake of $V$. anguillarum occurred at $60 \mathrm{~min}$ in a bacterial 
concentration of $1.5 \times 10^{7} \mathrm{CFU} \mathrm{ml}^{-1}$, while at a lower concentration of $1.5 \times 10^{6} \mathrm{CFU} \mathrm{ml}^{-1}$, a peak was observed after 120 mins. This may suggest that Artemia were able to utilize the potential probiont when given at higher concentration and different time. The delivery of probiont to the target host should also be considered since it is also important to choose the mode of delivery either through pharmaceutical formulations or via food-based products (Govender et al., 2014).

Moreover, probiont strain L11 showed ability to protect Artemia from $V$. harveyi infection with significant survival rate. According to Talpur et al. (2012) probiotic bacteria were able to reduce numbers of pathogen in Artemia compared with no probiotic added. Another study done by Giarma et al. (2017), found that the Artemia survivals were not significantly affected by different probiotic and different concentration of probiotic used. However, the probitic Bacillus was able to confer protection and increased survival rate after challenged with $V$. anguillarum. The used of probiont at concentration $10^{6} \mathrm{CFU} \mathrm{\textrm {mL } ^ { - 1 }}$ was recorded as a suitable concentration for Artemia. Furthermore, strain L11 applied at concentration of $10^{8} \mathrm{CFU} \mathrm{mL}{ }^{-1}$ was also able to reduce Vibrio loads in the Artemia at end of the challenge assay.

According to Lakshmi et al. (2013), crustacean such crabs are lack of immunoglobulin and lymphocyte in their immune system if compared with vertebrate. Since that, they only depend on their innate system as protector in open environment. Thus, the use of probiotic may able to provide protection and increase its growth rate. In this study, the preliminary test using Artemia, was found that strain L11 demonstrated good protection and able to colonize into the host faster. In in vivo study, $50 \%$ of mortality of crab juveniles were found after 5 days of challenge with $V$. harveyi with no probiont added. The adherence of the pathogen via flagellar motility tends to increase the ability to colonize and attached to host surface for infection (McCarter, 2004). Defoirdt (2013) stated that the crab juveniles death starts with the infection and multiplication of the pathogen inside the tissue and cell. These scenarios will cause a damaged to the crab tissue and the pathogen will leave the cell and back to water culture. The cycle will start all again and ready for next crab juvenile infect. However, the additions of the probiotic bacteria into the culture system will help to break the cycle.

Total plate count of Vibrios in culture water showed significant reduction after challenge assay. However, no reduction of Vibrios was found in the juveniles. This study also suggests that the concentration of probiont used should be higher than the pathogen to acquire full protection by inhibiting the growth of the pathogen. It was in line with study done by Vaseehan and Ramasamy, (2003) which suggested that the antagonist must be present at significantly higher levels than the pathogen and the degree of inhibition increased with the level of antagonist. The results agreed with study done by Talpur et al. (2012) which reported survival of blue crab larvae with probiotic are higher if compared with no probiotic.

Moreover, the used of probiont not only conferred protection to the juveniles but also able to increase weight since they only depend on their innate system as protector in open environment. In this study, the delivery of probiotics to the crab through water immersion is considered as the best methods since crab weight are slightly increased if compared to the crab weight without probiotic as supplements.

\section{CONCLUSION}

In this study, probiont B. amyloliquefaciens strain L11 was found not harmful to the Artemia nauplii and crab juveniles. It is also able to confer protection against $V$. harveyi which increased the survival of blue crab juveniles and decreased Vibrios load. It could be used as supplemental nutrient due to increase of the SGR of the juveniles in this study. Other than that, it also able to colonize in Artemia. Thus, this strain has a potential as probiont for crab cultures.

\section{ACKNOWLEDGMENTS}

This research was supported by Ministry of Higher Education Malaysia (MOHE) through SATREPS JICA-JST COSMOS 2016-2021 and Higher Institution Centre of Excellence (HiCoE) grant of Innovative Vaccine and Therapeutics against Fish Diseases, Vote No.: 6369100 and Universiti Putra Malaysia under High Performance Individual Research Grants UPM/700-2/1/ GPB/2017/9553100. 


\section{CONFLICT OF INTEREST}

The authors declare that there is no conflict of interest.

\section{AUTHORS' CONTRIBUTION}

All authors have made substantial, direct and intellectual contribution to the work and approved it for publication.

\section{DATA AVAILABILITY}

All datasets generated or analyzed during this study are included in the manuscript.

\section{ETHICS STATEMENT}

This article does not contain any studies with human participants or animals performed by any of the authors.

\section{REFERENCES}

1. Azrin N.A.R., Yuzine E., Ina-Salwany M.Y., Suzana R, Fathiah Masduki and Murni Karim. (2017). Murni Karim. (2017). Characterization of potential probionts from blue swimming crab Portunus pelagicus and its antagonistic activity against Vibrio harveyi. International Journal of Bio-sciences, 11(4): 292-303.

2. Campbell R., Adams A., Tatner M.F., Chair M., and Sorgeloos P. (1993). Uptake of Vibrio anguillarum vaccine by Artemia salina as a potential oral delivery system to fish fry. Fish \& Shellfish Immunology, 3(6): 451-459.

3. Defoirdt T. Virulence mechanisms of bacterial aquaculture pathogens and antivirulence therapy for aquaculture. Review in Aquaculture, 2013; 5: 1-15.

4. Frans I., Michiels C.W., Bossier P., Willems K.A., Lievens B., and Rediers H. Vibrio anguillarum as a fish pathogen: virulence factors, diagnosis and prevention. Journal of fish diseases, 2011; 34(9): 643-661.

5. Giarma E., Amanetidou E., Taufexi A. and Touraki M. Defense systems in developing Artemia franciscana nauplii and their modulation by probiotic bacteria offer protection against a vibrio anguillarium challenge. Fish and Shellfish Immunology, 2017; 66: 163-172.

6. Govender M., Choonara Y. E., Kumar P., du Toit L. C., van Vuuren S., and Pillay V. A review of the advancements in probiotic delivery: conventional vs. non-conventional formulations for intestinal flora supplementation. American Association of Pharmaceutical Scientists, 2014; 15(1): 29-43.

7. Hai N. V., Buller N., and Fotedar R. Encapsulation capacity of Artemia nauplii with customized probiotics for use in cultivation of wastern king prawn (Penaeus latisulcatus Kishinouye, 1986) Aquaculture, 2010; 41: 893-903.

8. Jithendran K.P., Poornima M., Balsubramanian C.P., and Kulasekarapandian S. Diseases of mud crabs (Scylla spp.): An overview. Indian Journal of Fisheries, 2010; 57(3): 55-63.

9. Korkea-Aho T.L., Papadopoulou A., Heikkinen J., von Wright A., Adams A., Austin B., and Thompson K.D. Pseudomonas M162 confers protection against rainbow trout fry syndrome. Journal of Applied Microbiology, 2012; 113: 24-35.

10. Lakshmi K., Viswanath B. and Sai Gopal D.V.R. Probiotics as antiviral agents in shrimp aquaculture. Journal of Pathogens, 2013; 13 p.p.

11. Lazado C.C., Caipang C.M.A., Brinchmann M.F., Kiron V. In vitro adherence of two candidate probiotics from Atlantic Cod and their interference with the adhesion of two pathogenic bacteria. Veterinary Microbiology, 2011; 148: 252-259.

12. McCarter L.L. Dual flagellar systems enable motility under different circumstances. Journal of Molecular Microbiololgy and Biotechnology, 2004; 7: 18-29.

13. Newaj -Fyzul A., Al-Harbi A., and Austin B. Review: developments in the use of probiotics for disease control in aquaculture. Aquaculture, 2014; 431: 1-11.

14. Sorroza L., Padilla D., Acosta F., Roman L., Grasso V., Vega J., and Real F. Characterization of the probiotic strain Vagococcus fluvialis in the protection of European sea bass (Dicentrarchus labrax) against vibriosis by Vibrio anguillarum. Veterinary Microbiology, 2012; 155: 369373.

15. Talpur A.D, Memon A.J, Khan M.I, Ikhwanuddin M, Danish Daniel M.M, and Abol-Munafi A.B. A novel of gut pathogenic bacteria of blue swimming crab, Portunuspelagicus (Linnaeus, 1758) and patho-genicity of Vibrio harveyi a transmission agent in larval culture under hatchery conditions. Research Journal of Applied Sciences, 2011; 6(2): 116-127.

16. Talpur A.D, Memon A.J, Khan M.I, Ikhwanuddin M., Danish Daniel M.M, and Abul-Munafi A.B. Effects of Lactobacillus Probiotics on the Enhancement of Larval Survival of Portunus pelagicus (Linnaeus, 175) Fed via Bioencapsulated in Live Feed. World Journal of Fish and Marine Sciences, 2012; 4(1): 42-49.

17. Tan L.T.H., Chan K-G., Lee L.H and Goh B.H. Streptomyces Bacteria as potential probiotics in aquaculture. Frontiers in Microbiology. 2016; 7: 79.

18. Vaseeharan B.A.R.P., and Ramasamy P. Control of pathogenic Vibrio spp. by Bacillus subtilisBT23, a possible probiotic treatment for black tiger shrimp Penaeus monodon. Letters in Applied Microbiology, 2003; 36(2), 83-87.

19. Verschuere L., Rombaut G., Sorgeloos P., and Verstraete W. Probiotic bacteria as biological control agents in aquaculture. Microbiology Molecular Biology Reviews, 2000; 641: 655-671. 